\title{
Teachers' Attitudes Towards Using First Language in English Classrooms: A Case Study of Kurdish Intermediate Teachers
}

\author{
Haval Abdulaziz Latif \\ Department of English, College of Languages, University of Human Development, Sulaymaniyah, Kurdistan Region, Iraq
}

\begin{abstract}
This study aims to shed light on the teachers' attitudes and insights towards using first language (L1) in intermediate English (L2) classrooms. It looks into the justifications and perceptions that teachers have regarding the use of Kurdish in English classrooms. More specifically, this study tries to find the major challenges that teachers face if the use of Kurdish language is ignored at intermediate schools. The analysis of this paper was based on a case study which was conducted on (10) intermediate English language teachers from (7) public and private schools in Sulaymaniyah. Qualitative methodology was applied by interviewing the participants virtually and asking the same open-ended questions. The results revealed that the majority of the teachers support the bilingual approach and the use of Kurdish language in intermediate English classrooms. Furthermore, the results showed that the teachers, to some extent, support the use of the Kurdish language to serve certain pedagogical functions, such as decreasing classroom anxiety, increasing students' participation, explaining difficult idiomatic expressions, giving test instructions, and facilitating classroom management. The findings of this study will help the intermediate English language teachers and learners to overcome the challenges they may face and, ultimately, improve the teaching and learning process.
\end{abstract}

Index Terms - English-Only Policy, First Language (L1), Foreign Language (FL), Second Language (L2), Teachers' Attitudes.

\section{INTRODUCTION}

Learning to articulate and communicate in foreign languages is, generally, a challenging process which requires numerous skills to be acquired. If the learner is surrounded by people who speak the foreign language, then the acquisition process becomes faster and less complicated. Nonetheless, the learner might become discouraged and less motivated if he or she is forced to use the foreign language without any integration of the first language. It is worth mentioning that the teacher's contribution and engagement in the process of learning the second language is, undoubtedly, very valuable and crucial as the teacher guides the students to produce and deliver the language effectively. Since English has become a global language or lingua franca, many people around the world have shown interest in learning it as a second or foreign language (Hasman, 2000). People with different linguistic, educational, racial, ethnic, and cultural backgrounds usually communicate with each other in English for various reasons. According to Graddol (2006), "English has become a key part in educational strategy in most countries" ( $p$. 70). Besides, the notion of Anglicization has dominated education and inspired many teachers around the globe to increase the use of English in their classrooms for the purpose of immersion.

Furthermore, many studies have been conducted in teaching methods and language acquisition due to the growing demand for learning English as a second or foreign language. Consequently, the significance of utilizing or avoiding the use of the first language in English classrooms has become a contentious and controversial issue. The monolingual and bilingual approaches are the two major opposing approaches that strongly influence the use of the first language in teaching English as a second or foreign language.

Much research on the use of the first language in EFL context has been conducted studying the teachers' and learners' attitudes and perceptions, including many studies in L1 Arabic, Persian, Turkish, Spanish, Malaysian, Chinese, Taiwanese, Japanese, and Vietnamese contexts. However, few research has been carried out in an L1-Kurdish context to study the teachers' attitudes towards using the first language in English classrooms. In other words, this study exclusively sheds light on using the Kurdish language in intermediate EFL settings to investigate teachers' attitudes towards using L1 (Kurdish) in FL (English) classrooms.

The purpose of this study is to examine whether the use of the first language in intermediate English classrooms hinders or facilitates the learning of a foreign language from the perspective of intermediate English language teachers. More precisely, this study explores the teachers' attitudes towards using Kurdish in intermediate English classrooms in the Kurdistan Region of Iraq. The research investigates the common issues and difficulties among native Kurdish teachers in teaching English as a Foreign Language (EFL). Based on the different methods and previous studies, this paper tries to find the major challenges that native Kurdish teachers face in

Journal of University of Human Development

Volume 7 No. 3(2021); DOI: 10.21928/juhd.v7n3y2021.pp115-126

Regular research paper: Received 28 July 2021; Accepted 22 August 2021; Published 25 August 2021

Corresponding author's e-mail: haval.latif@uhd.edu.iq

Copyright () 2021 Haval Abdulaziz Latif. This is an open access article distributed under the Creative Commons Attribution License (CC BY-

NC-ND 4.0) 
teaching English as a foreign language at intermediate schools. Through this study, issues such as decreasing the students' motivation, slowing down their progress, and lessening the threat of embarrassment will be addressed.

The study's purpose is not to overemphasize the role of L1 or advocate greater use of L1 in English classrooms but to discuss and clarify some conceptions such as whether the English teachers should use the L1 in class or when there is a need for it. English language teachers can benefit from this study as a source of information to take an overview of the issues and difficulties that occur among native Kurdish students who are studying English as a foreign language. This study also helps native Kurdish students in easing and accelerating the process of learning the English language. Additionally, the findings of this study will help teachers to better understand teaching strategies and determine, to which extent, the Kurdish language should be maximized or minimized in their English classrooms. The research explores the factors that may impact EFL students in learning the foreign language. This study aims to find answers for the following research questions:

\section{In which situations do teachers utilize or avoid using Kurdish in intermediate English classrooms?}

2. What are the positive and negative aspects of implementing the English-Only policy and ignoring the use of Kurdish language in intermediate English classrooms?

\section{VIEWS ON USING L1 AND FL IN ENGLISH CLASSROOMS}

The issue of using the first language in teaching or learning a foreign language has been controversial, and several supporting and opposing arguments have been raised. Methods that oppose L1 use, such as the Audio-lingual method, believe that using the first language might prevent learners from learning the second or foreign language. However, many studies suggest, as will be explained later in this paper, that the advantages of using the first language can outweigh the disadvantages if it is applied systematically and thoroughly. Studies revealed that many teachers and learners are in favor of using the first language in EFL context since they believe in it as a natural language facilitator and learning strategy. According to Macaro (2001), the first language must not be removed from the classroom pedagogy because it is a useful tool in language learning, and the teachers must include codeswitching in their class interactions in a non-harmful way. Employing the L1 may simplify classroom activities and instructions due to the fact that the use of L1 provides a valuable scaffolding which supports students in understanding tasks and solving specific problems.

Ellis (1984), Krashen (1982), and Yaphantides (2009) state that the integration of the first language may impede the process of learning the second or foreign language. However, Atkinson (1987), Auerbach (1993), Deller \& Rinvolucri (2002), Phillipson (1992), Prodromou (2002), Swain \& Lapkin (2000), Vanderheijden (2010), and Weschler (1997) support the concept of integrating the learners' first language to facilitate and accelerate the process of learning the second or foreign language. Carless (2008) states that the mother tongue potentially has both positive and negative consequences; it may serve social and cognitive functions. According to Liao (2006), students remain silent due to their nervousness or lack of English competence when the foreign language is the only medium allowed in discussions. However, there is more sustainable participation and meaningful communication when both L1 and FL are allowed as medium for discussion. The following section of this paper identifies approaches and studies that include or exclude the use of the first language in English classrooms.

\section{SUPPORT FOR FL USE IN ENGLISH CLASSROOMS}

Much research has been conducted to support FL use in English classrooms. These studies support the monolingual approach based on three essential and fundamental principles. The first principle focuses on the child's innate language learning. Children learn the language from exposure to the surrounding sound environment. They listen to their parents or other people in their surroundings, imitate them, and then respond to what they hear, and they succeed in mastering their first language. Therefore, Cook (2001), a pioneering advocate of L1, argues that supporters of L1 use state that exposure is crucial in the process of learning the foreign language because they believe that FL learning follows a process similar to L1 acquisition. In particular, foreign language learners should be exposed to an EFL environment as much as possible. According to Krashen (1986), as cited in Brown (2000), an expert in the field of linguistics and a critical advocate of only using the second language in the classroom, "Comprehensible input is the only causative variable in second language acquisition" ( $p$. 280). He believes that success in a foreign language can be attributed to input alone.

Concerning the second principle, supporters of L1 point out that the main barrier to learn the foreign language is the interference from the L1 knowledge (Cook, 2001, p. 407). Krashen (1981), in his influential "Second Language Acquisition and Second Language Learning", suggests that the L1 is a source of errors in learners' L2 performance (p. 64). He indicates that a high amount of first language influence is found in situations where translation exercises are frequent (ibid., p. 66). Regarding the third principle, the use of the second language for all interactions in the L2 classroom can declare the importance of the L2 in fulfilling learners' communicative needs (Littlewood, 1981 as cited in Cook, 2001, p. 409) and describing usage of the second language (Pachler \& Field, 2001).

Other arguments indicate that using the first language might discourage the second language learners to use the L2 and deprive them of input in the second language when the teacher uses the first language (Krashen 1988, in Prodromou 2002; Ellis 1984, in Hawks 2001). Moreover, Carless (2008) claims that the negative impact of mother tongue use is that too much reliance on the first language may undermine interaction in English (p. 331). Additionally, the students should also be exposed to the foreign language in order to maximize motivation and the use of the foreign language. Rolin-Ianziti \& 
Varshney (2008) claim that the use of the first language for some students might appear to play a crucial role in attaining explicit information of the linguistic features of the foreign language. Although the frequent use of the L1 might alleviate classroom anxiety and help to build constructive relationships between learners and teachers, it might also minimize motivation and slow down the process of learning the second or foreign language.

\section{SUPPORT FOR L1 USE IN ENGLISH CLASSROOMS}

According to Baker (2011), bilingualism is the ability to communicate in one language fluently while communicating in another language less fluently. Supporters of the first language use in EFL classrooms believe that the FL learners can acquire the foreign language more efficiently if the native language is used. Turnbull (2001) states that the use of the second language should be maximized; however, increasing L2 use does not and should not mean that it is harmful for the teacher to use the first language. A principle that promotes maximal teacher use of the L2 acknowledges that the L1 and L2 can exist simultaneously. Likewise, Schweers (1999) conducted a research at the University of Puerto Rico on the use of Spanish in English classrooms to see how often teachers used the L1 in their English classrooms. Schweers' (1999) study showed that almost all the students agreed with the use of Spanish in English classrooms because they believed that L1 use could help them understand the texts and feel more comfortable.

Al-Nofaie's (2010) study in Saudi Arabia indicated that the Saudi students' and teachers' attitudes towards using Arabic in the English classrooms were positive. Besides, the study revealed that using Arabic was preferred in certain situations, such as explaining difficult concepts, clarifying some idiomatic expressions, assessing comprehension, organizing tasks, defining new terminologies, disciplining students, and giving test instructions. The Saudi teachers highlight the importance of using Arabic in their English classrooms. Nevertheless, they claim that excessive and untimely use of Arabic should be avoided because it might impede and slow down the process of learning English.

Using the first language can serve students as a significant instrument to understand and comprehend the content of the task. Likewise, the socio-cultural theory of mind approach concentrates more on the language form, the use of vocabulary, syntactical structure, and general management. Cook (2001) investigates the concept of first language use by both teachers and students in classroom settings but supports using the native language so as to create positive links between the first and second languages. Teachers can benefit from using the L1 to convey their thoughts of such meanings, elucidate grammatical structures, and manage classrooms. In addition, Cook (2001) states that using the first language in class can be a helpful and functional tool in establishing authentic second language use.

Kim Anh (2010) conducted a study on Vietnamese teachers to find out what their attitudes were towards using Vietnamese in English classrooms. The results of the study revealed that careful and judicious use of the L1 in teaching English is necessary in some situations, such as explaining abstract vocabulary, idiomatic phrases, phonology, and pragmatics. All of the Vietnamese teachers supported the use of the mother tongue in their English classrooms. They emphasized that the first language could play a positive role in their English classrooms, and it was a part of their teaching methodologies and curriculum. Ovando, Collier, and Combs (2006) argue for the use of the L1 as a strategy and platform for instruction in social studies or other subject matter when the L1 resources are available. In other words, cognitive and academic developments are facilitated when the language that students know best is utilized.

Ramachandran (2004) did an experimental study and showed that the translation method, which involves using the students' first language as the medium of instruction, led to more vocabulary acquisition than L2-only instruction among elementary Malay EFL learners. Regarding the use of L1 in teaching L2 and its influences on threatening learners' identity, Cook (2007) argues that the students' first language should, by all means, be acknowledged. The importance is highlighted even more by the fact that the students' culture is part of their language and by neglecting their language, the teacher neglects their culture, which leads to the danger of neglecting their linguistic and cultural identity as well.

\section{ADVANTAGES OF USING L1 IN ENGLISH CLASSROOMS}

In accordance with Kerr (2019), learning is a complicated process and both first and second languages are and will be intertwined in terms of syntax, phonology, sentence processing, and vocabulary since both language acquisitions occur in the same human mind. A number of studies have explored the different ways in which teachers use the first language. These can be predominantly divided into two categories: 'core functions' and 'social functions' which are displayed in the following table:

\section{(Table 1) \\ Core and Social Functions for L1 Use, adopted from (Kerr, 2019, p. 5)}

\begin{tabular}{|l|l|}
\hline \multicolumn{1}{|c|}{ Core Functions } & \multicolumn{1}{|c|}{ Social Functions } \\
\hline \multicolumn{1}{|c|}{$\begin{array}{c}\text { Concerned with language } \\
\text { teaching }\end{array}$} & \multicolumn{1}{|c|}{$\begin{array}{c}\text { Concerned with classroom } \\
\text { management }\end{array}$} \\
\hline $\begin{array}{l}\text { - explaining grammar and } \\
\text { vocabulary } \\
\text { - checking understanding of } \\
\text { grammar, vocabulary, and texts }\end{array}$ & $\begin{array}{l}\text { • managing personal } \\
\text { relationships (e.g., building } \\
\text { rapport, maintaining } \\
\text { discipline) } \\
\text { • giving instructions } \\
\text { • dealing with administrative } \\
\text { matters }\end{array}$ \\
\hline
\end{tabular}

There is no evidence that the 'core functions' and 'social functions' for L1 use in language teaching are in any way detrimental to learning as long as it is not overused. Rapport development and discipline maintenance seem to be the most common. For instance, expressions of sympathy are better understood by lower-level learners if formulated in the L1 (Hall $\&$ Cook, 2013). The teacher's decision to use the L1 for core or social functions is often driven by a desire to expedite the class 
activity or to keep the lesson moving (Macaro, 2005). There are numerous advantages of implementing the L1 in English classrooms, and many academics and scholars support this notion due to its significance, need, and positive impact. Consequently, considerable advantages have been proposed:

- The use of the first language lowers learners' anxiety (Auerbach, 1993 as cited in Hawks, 2001), and it establishes a more peaceful learning environment (Burden, 2000; Phillips, 1992).

- It is a method of bringing the learners' cultural background knowledge into the class (Prodromou, 2002).

- Teachers benefit from the use of the L1 in giving instructions and checking students' understanding (Atkinson, 1987).

- The use of the L1 helps in clarifying the differences in pronunciation and grammar between the first and second languages and explaining the meaning of abstract words (Buckmaster, 2002; Cole, 1998).

- L1 use develops the teacher-student relationships, facilitates communication, and accelerates the process of learning the foreign language (Harbord, 1992, p. 354).

- The use of the L1 can save time and avoid confusion. Teachers are allowed to use more authentic texts to promote and stimulate more comprehensible input and faster acquisition (Harbord, 1992, p. 351).

- L1 use may assist students in reducing affective barriers and increasing their confidence in their ability to successfully comprehend the L2 (Atkinson, 1987; Auerbach, 1993; Cook, 2001; Harbord, 1992; Johnson \& Lee, 1987; Kang, 2008; Kern, 1989).

- The L1 is an indispensable tool for making meaning of text, retrieving language from memory, exploring and expanding content, guiding students' action through the task, and maintaining dialogue (Villamil and de Guerrero, 1996, p. 60).

- Translation, one way of using the first language, improves students' ability to read English in terms of assessing reading comprehension, reading strategies, vocabulary, and cultural background knowledge (Hsieh, 2000 as cited in Pan, 2010).

Researchers acknowledge that the English-Only policy is not a crucial and pedagogical factor to improve learning English; the use of L1 is efficient and essential in some contexts. According to Deller (2002), "The mother tongue taboo has been with us for a long time, but fortunately, now things seem to be changing. I believe that many teachers have continued to use the mother tongue because it is both necessary and effective" (p. 3). Similarly, Husain (1995) argues that the use of the first language provides EFL learners with a quick and effective method for analyzing and comprehending the structure of the foreign language. Moreover, Storch and Wigglesworth (2003) engaged twelve pairs of students in a short collaborative composition activity. They discovered that the use of the first language enabled thorough and in-depth discussion of the prompt and the structure of the composition; therefore, the students could accomplish the task more smoothly and effortlessly. Likewise, the use of the L1 helped the students in defining anonymous words more directly and effectively.

\section{DISADVANTAGES OF USING L1 IN ENGLISH CLASSROOMS}

The use of the first language is a helpful facilitator for second language learning. According to Atkinson (1987), the L1 is considered beneficial for a large number of L2 learners because it strongly affects the learners' preferred strategies of learning. In contrast, a substantial number of scholars (Turnbull \& Arnett, 2002; Levine, 2003; Nation, 2003; Scott \& de la Fuente, 2008; Littlewood \& Yu, 2009) claim that using the first language in English classrooms might discourage the learners and impede the process of second language learning. Therefore, it is crucial to engage learners in the second language only. Additionally, Krashen (1981), in his inspiring hypothesis of 'comprehensible input', states that the first language should be excluded, and the second language should be taught and learned through second language only. If the L1 is excessively used in English classrooms, it may negatively influence the process of learning the second or foreign language. Consequently, considerable disadvantages have been proposed:

- Some teachers may over rely on using the first language and discourage the students to learn the foreign language (Polio, 1994, p. 153).

- It can minimalize the use of English language (Atkinson, 1987, p. 247).

- Students become lazy in finding synonyms in English, and they try to translate the new words into their native language. Hence, they learn a limited amount of vocabulary (Atkinson, 1987).

- Frequent translation to the first language creates the problem of oversimplification because many cultural and linguistic nuances cannot be directly translated (Harbord, 1992). For instance, "That's so cool!" in English implies that something is wonderful or astonishing.

- Translation of English into the first language may adversely influence students' learning process. The direct and simple way of translation will make L2 knowledge less memorable since the process lacks mental efforts, such as working out meaning from context (Thornbury, 2010).

Students may think in the first language if the L1 is overused in class, which may hinder the advancement and development of learning English. As stated previously, learning English can be influenced negatively if the L1 is overused or misused. Therefore, teachers should be mindful and careful of the amount of L1 used in English classrooms.

\section{SITUATIONS OF USING L1 IN ENGLISH CLASSROOMS}

Many researchers, including Atkinson (1993), Auerbach (1993), and Cook (2013), claim that the use of L1 can play a 
vital role in English classrooms, especially if the learners and teachers share the same linguistic and cultural backgrounds. These scholars argue that L1 should be used in some situations and should be avoided in some other situations. Hence, the researchers suggest many specific situations for the teachers in which L1 is permitted. For example,

- According to Cook (2013), the use of L1 is permitted in conveying and checking the meaning of abstract words, clarifying grammatical rules, organizing the class, managing tasks and activities, and maintaining discipline.

- De La Campa and Nassaji (2009) state that the L1 is allowed for comprehension checks, translation, activity instruction, and classroom management.

- Furthermore, Atkinson (1987) claims that the use of the $\mathrm{L} 1$ can be expedient in giving instructions and helping learners cooperate with each other (p. 243).

Bozorgian \& Fallahpour (2015), in their research examining the amount and purpose of using L1 (Persian), discovered that teachers used L1 for (16) purposes, while students used it for (5) purposes in English classrooms. Amount and purpose of L1 use are displayed in the following tables:

(Table 2)

Teachers' Amount and Purpose of L1 Use, adopted from (Bozorgian \& Fallahpour, 2015, p. 77)

\begin{tabular}{|l|c|}
\hline Teachers' Purposes & Percentage \\
For L1 Use & $20 \%$ \\
\hline 1. Translation & $17 \%$ \\
2. Elicitation of students' contribution & $12 \%$ \\
3. Activity instructions & $4 \%$ \\
4. L1-L2 contrast & $3 \%$ \\
5. Activity objectives & $3 \%$ \\
6. Teacher as bilingual & $3 \%$ \\
7. Reaction to students' questions & $3 \%$ \\
8. Personal comment & $2 \%$ \\
9. Comprehension check & $2 \%$ \\
10. Encouraging & $1 \%$ \\
11. Humor & $1 \%$ \\
12. Evaluation & $1 \%$ \\
13. Giving reference & $1 \%$ \\
14. Administrative issues & $1 \%$ \\
15. Classroom equipment & $1 \%$ \\
16. Repetition of students' L1 utterance & \\
\hline Total: & $75 \%$ \\
\hline
\end{tabular}

(Table 3)

Students' Amount and Purpose of L1 Use, adopted from (Bozorgian \& Fallahpour, 2015, p. 77)

\begin{tabular}{|l|c|}
\hline \multicolumn{1}{|c|}{$\begin{array}{c}\text { Students' Purposes } \\
\text { For L1 Use }\end{array}$} & Percentage \\
\hline 1. Asking questions & $11 \%$ \\
2. Answering & $7 \%$ \\
3. Clarification & $5 \%$ \\
4. Scaffolding & $1 \%$ \\
5. Self-correction & $1 \%$ \\
& \\
Total: & $25 \%$ \\
\hline
\end{tabular}

Butzkamm (2003) states, "The mother tongue is generally regarded as being an evasive maneuver which is to be used only in emergencies" (p. 29). In other words, the first language should only be used when necessary. Moreover, students should be allowed to use code-switching when they find difficulties in completing a task or conveying their messages. Thus, students will be encouraged to participate in class discussions vigorously and enthusiastically. The suggested situations, which was mentioned previously, depend on the teachers' perceptions and assessments. To put it another way, teachers should take the aim of the lesson and learners' abilities into consideration when the interference of the first language is needed. Altogether, it is obvious that the different functions of classroom L1 used by the teacher can play an essential role in accelerating the process of language learning. Linguistic and non-linguistic factors should be considered by teachers when making decisions about whether or not to use the L1. Its role is likely to be more crucial with lower-level and younger learners (Scheffler \& Domińska, 2018).

\section{MATERIALS AND METHODOLOGY}

With the intention of examining the hypothesized issues and questions, this study explores the teachers' attitudes towards using Kurdish as the first language in intermediate English classrooms. This research was carried out in Sulaymaniyah, in the Kurdistan Region of Iraq. This case study involved (10) intermediate adult English language teachers, five males and five females, who are currently teaching at (7) public and private intermediate schools in Sulaymaniyah. All the participants' nationality is Iraqi, and their first language is Kurdish. Interviews were employed as a research instrument and method for collecting the data by using Zoom (a video conferencing application platform that allows users to make voice calls and virtually meet with each other).

The interviews were semi-structured and conducted in English, and each participant was asked the same questions. Prior to conducting the interviews, the teachers were asked to electronically sign consent forms. They were informed that their personal data and responses will be kept strictly confidential, and that the information will not be revealed nor used for any other purposes, and only aggregated results will be reported in reputable academic publications.

In order not to disclose the participants' real names, the confidentiality of the teachers is ensured by choosing English common names as pseudonyms for each participant (Angela, Donnie, Jennifer, John, Joseph, Kenneth, Kevin, Latricia, Ruth, and Tamara). Furthermore, relevant biographic data were collected, including an understanding of the teachers' professional contexts (level of class, type of school, typical number of students per class), and their professional credentials and experience. The teaching experience of the participants ranged between (3-10) years.

The teachers were interviewed individually, and the duration of each interview session was approximately (25-30) minutes. Open-ended and follow-up questions were raised. The interviewees' responses to the research questions were recorded and transcribed. In other words, their transcribed responses will be analyzed and discussed as data of this study. Qualitative 
approach methodology will be implemented for analyzing the participants' responses thematically. The findings of this study will be interpreted based on the adequate and authentic responses of the participants. The interviewees reported their attitudes towards using Kurdish as a first language and explained their justifications for accepting or rejecting its integration in their English classrooms.

\section{ANALYSIS AND DISCUSSION}

Since the interviewees were asked the exact same questions and many of the responses were similar, common responses were selected and analyzed thematically. Applied Thematic Analysis (ATA) was used as a multiple analytic technique to analyze the transcribed data, identify patterns and themes, and provide a rationale for this study which, according to Guest, MacQueen, and Namey (2014), "Thematic analyses move beyond counting explicit words or phrases and focus on identifying and describing both implicit and explicit ideas within the data, that is, themes" (p. 9). Analysis of interview transcripts proffer deep and rich insight into teachers' attitudes towards using Kurdish in intermediate English classrooms. Results reported in this section include themes, patterns, and representative examples from the interviewee's responses.

\section{In which situations do teachers utilize or avoid using Kurdish in intermediate English classrooms?}

The study revealed that the participants have various reasons and perspectives towards using or avoiding Kurdish in their English classrooms. Teachers highlight the importance of using the first language in their classrooms, and they prefer using Kurdish in certain situations, such as explaining abstract vocabulary and simplifying grammar rules and phonology. Additionally, the teachers indicated that using Kurdish in their English classrooms can help them in clarifying instructions, managing classroom activities, maintaining discipline, and alleviating classroom anxiety.

\section{Jennifer says: \\ "I sometimes use Kurdish language in my English classes in certain circumstances, especially with weak learners. For example, the receiver or learner sometimes cannot understand my point and asks me to explain it further in the L1. Then, whether we want it or not, I am obliged to explain the point in Kurdish which can help in clarifying the meaning and, therefore, make the students more comfortable. However, I think maximizing the use of the L1 may decrease students' motivation since EFL learners are less exposed to the foreign language outside of the classroom."}

Jennifer partially agrees with the notion of employing Kurdish language in her English classrooms to help the students understand her point better. She thinks that if the first language is used in an effective way to convey meaning, then the students will feel more tranquil in using the foreign language. Hence, the students' ability to learn the foreign language will improve as well. Johansson (1998) states that the differences of meaning and vocabulary in both first and second languages cannot only be covered by providing the same translation, whereas teachers need to use the first language in order to deliver the message and make the meaning clearer.

Burden's (2001) study showed that both students and teachers believe in the importance of the L1 in explaining new terminology, providing instructions, taking tests, teaching grammar, checking for understanding, and comforting the students. Nonetheless, teachers should raise learners' attention towards the importance of maximizing the use of the second language in order to prevent the overuse of the first language which might reduce the students' performance, competence, and language proficiency.

\section{Joseph says:}

"I think using Kurdish language is necessary, and I personally use it when I explain rules of grammar, phonetics, and explain the meaning of foreign words so that my students can understand the subject in the best way possible, which is the objective of my teaching. I do my best to find equivalent words in Kurdish because this would further help my students visualize the phrases in their minds which will positively affect the learning process."

Joseph is positive towards using Kurdish in his English classrooms. He states that he uses the L1 to clarify and elucidate some grammatical and phonological rules and explain some English expressions in Kurdish when necessary so the students can portray a visual image in their minds. Willis and Willis (2007) consider that the L1 cannot be avoided in L2 classrooms since it can bring some benefits to the classroom, especially with weak learners. For instance, some teachers have found that learners who performed a task in their L1 before doing it in the L2 showed good progress in the L2. More explicitly, the L1 can be used with those words which are difficult to explain or infer. In addition, task instructions could be given in the L1 to check learners' understanding. European scholars claim that translation should be avoided although the first language could be used in order to explain new words or check students' comprehension (Richards and Rodgers, 2001).

Kevin says:

"There are so many reasons which encourage me to use Kurdish in my English classes. It can help the students understand me in a clearer and easier way, and there is another point which has to do with my students. My weak students ask me to speak in Kurdish because they struggle in understanding the topic and cannot participate in group work activities, but I think the overuse of the Kurdish language might affect my classes negatively."

Kevin states that his lower-level learners are unable to participate in class activities and that they need help in clarifying the message in their L1. Nonetheless, he thinks that the excessive use of the first language might hinder his 
students' abilities and adversely impact their progress. Schweers (1999) argues that if learners of a second language are encouraged to ignore their native language, they might feel their identity is threatened and, therefore, their language progress might decline.

Donnie, on the other hand, relates the use of the first language in his English classrooms to the unavailability of teacher training programs and authentic curricula. He also adds that the use of the old language methods such as grammar-translation method and the large number of students in class are other reasons behind using Kurdish in his English classrooms. He says:

\begin{abstract}
"I usually use Kurdish in my English classes because the previous teachers were applying the grammar-translation and audio-lingual methods and the students are used to the old teaching methods. I personally prefer using direct method and communicative approach. However, the students' levels are not advanced enough to completely avoid the use of Kurdish. Moreover, the school lacks teacher training programs and new curricula. There are 48 students in my class which is impossible to control and manage the classroom without using the L1."
\end{abstract}

Donnie thinks that there are many pedagogical and academic shortcomings which interfere with the students' performance and teaching the foreign language. Furthermore, the inaccessibility of adequate teacher training programs is also problematic. The methodological teaching principles should develop students' communication skills in English. Teaching in overcrowded classes is another major reason that compel the teachers to unintentionally use the $\mathrm{L} 1$ in order to manage their classrooms.

Kenneth shares his own personal teaching experience and explicates that the proficiency level of many of his students had declined and their test scores had decreased dramatically when they realized that the teacher had attempted to maximize the use of English and avoid the use of Kurdish. He says:

"According to my experience as a teacher who has been teaching English for beginner and intermediate learners in Kurdish EFL context, excluding the mother tongue in English classrooms will impact the learners in a negative way. When I tried to use English language without using any Kurdish expressions, the proficiency level of many students had dropped. When I asked them about the reasons of scoring very low on quizzes and tests, they stated that it was impossible for them to understand anything when the LI was completely ignored."

Based on Kenneth's personal experience and assessment, using the L1 in intermediate English classrooms is critical and necessary, especially when the majority of the students score low on standardized tests due to the absence of employing the L1. According to Boston's Haitian Multi-Service Center as cited in Auerbach (1996), students who report having dropped from English classes due to limited L1 literacy and schooling return to classes when the L1 literacy is offered. Likewise, the report accentuates the significance of $\mathrm{L} 1$ use because it reduces the affective barriers in second language acquisition and, therefore, allows for more rapid and systematic progress.

John says:

"As an English teacher, who has been teaching for nine years, I believe If you teach at an intermediate school, you are required to use the L1 because your students may not have a broad knowledge of the foreign language. However, if you teach at a university level and particularly at English department, then you are not required to use the L1. Therefore, I do believe in the use of L1 in intermediate English classrooms because the teachers can simplify some misconceptions and warn student when they misbehave."

John asserts that the use of the first language at intermediate schools can be a beneficial and valuable method in improving the students' comprehension, and teachers can sometimes use it to maintain discipline. According to Azrien et al., (2014), learners will be able to comprehend the subject matter more efficiently if the explanations are given in their own language, and a teacher can avoid using the L1 if the students have academic experience in the foreign language. In addition, students use the L1 to expedite the comprehension process and lessen any uncertainties and insecurities that may arise from their limited language proficiency. Teachers use L1 to enhance knowledge that students have learned about the foreign language, such as elucidating abstract vocabulary, sentence formations, and cultural aspects.

2. What are the positive and negative aspects of implementing the English-Only policy and ignoring the use of Kurdish language in intermediate English classrooms?

It is obvious that the implementation of the English-Only policy in intermediate English classrooms has both merits and demerits. Many researchers believe that this policy might affect the students' confidence who have lesser knowledge in English. Tsao \& Lin (2004) provided a research result about the EnglishOnly instruction in Taiwan. They emphasized that ignoring the first language and implementing the English-Only policy improves students' listening comprehension. However, they claimed that employing such policy does not bring any considerable change on students' learning anxiety, motivation, and attitudes. Likewise, their experimental research concludes that the Taiwanese language should be allowed in English classrooms because it advances the interaction between the teachers and students.

Most of the participants in this case study accentuate that ignoring or prohibiting the use of Kurdish language and implementing the English-Only policy in intermediate English classrooms will definitely do more damage which negatively influence the students' competence, confidence, and language proficiency. 


\section{Tamara says:}

"We must understand that by employing such policy, we are implementing an idea that we are forcing the students into doing something more challenging. These are students and, on top of that, they are still young, and this policy may damage their confidence. Once their confidence is misplaced, it is hard to rectify it, and they may fix it in harmful ways like hating the lesson or the teacher. We need to pave their journey carefully that they are inclined to walk it willingly."

Tamara states that challenging the students by imposing the English-Only policy and not allowing them to communicate in Kurdish in intermediate English classrooms may damage their self-confidence, and it can be difficult to remedy. She suggests using both languages so as to create a positive, vigorous, and healthy learning environment for the students. According to Seng and Hashim (2006), lower proficiency students usually have difficulty conveying or verbalizing their thoughts with confidence and accuracy; thus, they should be allowed to rely on L1 to understand the foreign language effortlessly.

\section{Angela says:}

"Some teachers avoid the first language while teaching intermediate students and try to implement the English-Only policy because they believe that avoiding the first language makes the language learning ideal. According to my personal experience as a language learner and current teacher, the use of both languages simplifies the process of learning. Teachers can also apply different teaching methods and techniques to effectively mix both languages in their English classrooms."

Angela believes that if the teacher only depends on English in teaching the intermediate students, it will adversely affect them since their language aptitude is not advanced enough, and they may not be able to comprehend the lesson. In addition, she asserts that a variety of teaching strategies and methodologies can be blended in order to teach the lesson efficiently and successfully. According to Dixon et al., (2012), since bilingual students may have little or no exposure to the L2 outside the school, it is critical for teachers to understand the process by which the L2 should be taught. The L1 should be utilized as a support in order to ensure understanding and learning.

Ruth says:

"Some teachers tend to avoid using Kurdish and employ the English-Only policy. They think that they are helping the students by forcing the foreign language. I think this method is harmful because lower-level students will suffer the most. Students at such ages are sensitive and narrowing down their ways may induce a helpless environment in which the teacher may kill the students' enthusiasm to learn. We need to be careful in representing ourselves because we may appear deleterious which is not the impression we want our students to have."

Ruth also disagrees with the notion of implementing the English-Only policy and ignoring the use of Kurdish language in intermediate English classrooms. She claims that imposing the foreign language may hurt the students' feelings and obliterate their eagerness and passion to learn English. Additionally, the rigorous usage of only one language may obviate the students from interacting with each other as well as the teacher. According to Hiroko, Miho \& Mahoney (2004), "Many Japanese students express their unwillingness to participate in an English-Only class and they prefer that their teachers use Japanese in their English classrooms when needed" (p. 486).

\section{Latricia says:}

"There are two sides to every coin. In my opinion, maximizing the use of the foreign language has the advantage of students being directly exposed to English, and they are pushed to acquire the language since it will be a direct need to their accomplishments. However, the negative effect would be on students who are still building their English basics. It would affect those students, and, in many ways, I have noticed that they will become hopeless and will lose their interest in the subject."

Latricia partially agrees with the concept of employing the English-Only policy in intermediate English classrooms. She believes that students' direct exposure to the foreign language will help them develop and improve the language skills more rapidly and effectively. According to Glazer et al. (2017), English language acquisition has become an enlightening priority in today's worldwide community; hence, it is vitally important for anyone to learn the English language properly. Young L2 learners have to acquire academic English to interact in an English conversation whether in or out of school. Latricia, on the other hand, believes that lower-level students may lose their enthusiasm, become desperate, and discontinue their schooling if the L1 is utterly ignored.

Jennifer says:

"I have personally seen benefits in using the LI while teaching English, and this policy cannot be applied at the intermediate level. Many of my students struggled to generate sentences. They misused certain words because they didn't know their meanings in English, and I had to clarify. We should make the students aware of what certain words imply, especially when the sentence has an idiomatic feature exclusive to English. After all, the teacher is making the learning journey easier and more comfortable."

Jennifer is also in opposition to the idea of applying the English-Only policy. She emphasizes that it is futile and ineffective to entirely ignore the L1 because some students at the intermediate level are unable to formulate sentences. She 
adds that the teacher should not be reluctant to elucidate certain idiomatic expressions in their L1. Teaching a language should be adjusted to the needs of the students. Ortego (1973) states, "The innovative approach attempts to adjust the curriculum to the students. It starts out with the students at whatever place they are on the learning ladder and adjusts the curriculum to the interest or learning level which the students demonstrate" (p. 118).

\section{Kenneth says:}

"I think many students will struggle with expressing themselves in English if this policy is applied at intermediate schools. We need to remember that not every student at this particular level is an advanced speaker, and such policy might be a pressure that they cannot handle. Making students feel insecure or doubt their capabilities is not the way we encourage our learners. It is also vital to use L1 to clarify exam instructions and make sure everyone has understood the requirements."

Kenneth is not supportive of employing the English-Only policy in intermediate English classrooms. He believes that some students' language abilities are not sophisticated at this particular level, and they may not be able to communicate and articulate utterances effortlessly. Therefore, students may feel anxious and vulnerable. He adds that utilizing the L1 is beneficial in elucidating exam questions and directions. A study was conducted by Auerbach (1993) on the notion of utilizing the English-Only policy, and she wanted to ascertain if such movement can be exploited or avoided. She claims that the teachers can eventually determine whether they should employ or avoid the L1 use. Hence, the teachers are the ones who advise, guide, advocate, and support their students since every classroom is unique and different. She suggests some justifications for employing the L1 in English classrooms:

- Utilizing the L1 minimizes and lessens barriers to learn English and builds a strong relationship between teachers and learners.

- The use of L1 encourages the students to vigorously participate in class and develop their self-confidence.

- It is noticed that teachers who allow their students to use their L1 had acquired English more rapidly than those who employ the English-Only policy in their classrooms.

The findings of this research revealed that all the (10) teachers participating in this case study acknowledge that the L1 (Kurdish) should be employed in intermediate English classrooms in some situations to serve certain pedagogical functions, such as explaining syntactical items, conducting class management, giving directions, introducing new phrases, clarifying idiomatic expressions, maintaining discipline, organizing activities, assessing students' comprehension, and elucidating exam instructions. Likewise, teachers' choice of pedagogical functions might be influenced by their attitudes towards students' personalities, classroom settings, number of students per class, and institutional practices. Nevertheless, some participants claim that the excessive use of the L1 might hinder and hamper the students' abilities and adversely impact their progress.

Concerning the second research question, (8) out of (10) participants in this case study indicated that ignoring or prohibiting the use of Kurdish language and implementing the English-Only policy in intermediate English classrooms will certainly do more damage which adversely influence the students' language proficiency, confidence, and development. Nonetheless, (2) out of (10) participants, to some extent, agree with implementation of the English-Only policy. They asserted that students' direct exposure to the foreign language will help them enhance their listening and speaking skills swiftly. According to Huang (2009), English-Only education improves students' vocabulary and listening proficiency. Students also develop more confidence when they are required to express themselves in spoken English. However, it is predictable that students may confront nervousness, tension, and stress from other classmates.

The essential themes arising from the analysis of this research are consistent with aforementioned relevant studies in this field. The participants acknowledged that they should be considerate and thoughtful towards the students since most of them do not have sufficient exposure to English language and they may find it difficult to comprehend foreign concepts. Furthermore, the interviewees believe that the L1 use in English classrooms facilitates students' understanding of ambiguous concepts, and this perspective supports the results of many studies discussed in the literature. De la Campa \& Nassaji (2009), Lin (2013), and Macaro (2001) claim that L1 serves as a valuable cognitive tool which supports learners to comprehend the concepts and understand the world.

The use of L1 also serves as a social tool to sustain the purpose of communication in EFL setting, and according to Vygotsky's (1976) sociocultural theory, social interaction mediates cognitive development. He believes that learning is reflected by cultural artifacts such as language, and a strong rapport will be developed between students and the social world such as peers and teachers. Based on Vygotskian psycholinguistics, students use the L1 as a powerful tool for interacting in the inter-psychological and intra-psychological levels. Nonetheless, overuse of learners' L1 prevents students' input of English language.

\section{CONCLUSIONS, IMPLICATIONS, AND LIMITATIONS}

The overall findings of this study revealed that intermediate English language teachers in Kurdistan Region of Iraq support the use of the Kurdish language in their English classrooms in certain situations. The transcribed interview data indicated that, predominantly, all the teachers participating in this case study do believe in the effectiveness and importance of using the Kurdish language in intermediate English classrooms. On the other hand, since EFL learners are less exposed to the foreign language outside of the classroom, the interviewees believe that excluding the foreign language might hinder and slow down the learners' progress in English and decrease their motivation to learn a new language. 
Likewise, the findings of this research showed that there are many motives and reasons behind employing Kurdish in English classrooms, such as explaining grammatical rules, conducting classroom management, delivering messages, introducing new phrases, maintaining discipline, organizing activities, and elucidating exam instructions. The study also investigated whether the use of the first language helps EFL learners understand difficult concepts, such as clarifying idiomatic expressions, assessing comprehension, explaining abstract vocabulary, and giving directions.

The participants perceived the positive role of L1 in their intermediate English classrooms, and they recognized the students' L1 not only to enthuse the students to participate but also to enhance their English competence. Besides, most of the teachers in this study believe that the bilingualism approach can tremendously help the students develop their cognitive skills and build rapport with fellow students and teachers. In contrast, few teachers believe that the use of L1 in their classrooms precludes students' input of English proficiency. In their perspectives, English language should be the medium of instruction because they think the L1 confines students' ability to improve language skills competently.

The students' first language should only be utilized to help simplify interpersonal communications, improve language competence, and construct knowledge in English. By no means should L1 be awarded the same significance as English in the intermediate English classrooms. Foreign language teachers are expected to help their students benefit from their native language so as to accelerate the progression of English language learning. Research studies have proved that the L1 is not only an efficacious teaching method but also a valuable learning tool if pedagogical activities are well conceived.

Additionally, students use the L1 to lessen any nervousness and insecurities that may arise from their inadequate language proficiency. Teachers usually use the L1 to scaffold and develop students' knowledge including cultural, linguistic, and non-linguistic aspects. The proper amount of utilizing the $\mathrm{L} 1$ by teachers and students in English classrooms depends on students' proficiency levels, teaching purposes, classroom settings, and students' needs. The first language may be used from basic to lower-intermediate levels on a decreasing scale to, gradually, reduce the use of the L1 and maximize the use of the foreign language.

The pedagogical implications of the study signify that, to some extent, Kurdish language should be used in intermediate English classrooms to teach English pragmatics to Kurdish EFL learners. The findings of this study can help teachers adjust their teaching strategies and curriculum and also understand their students' attitudes towards the use of the L1. Similarly, students may come to a better understanding of why they tend to use their first language in English classrooms. Moreover, the study suggests that the Ministry of Education in Kurdistan Region of Iraq should train the English language teachers and provide them with adequate resources to improve their competence in teaching English pragmatics.

The results of this qualitative study should be limited to the sample of this research and cannot be generalized to different subjects since it focuses on a small number of teachers who teach English at intermediate schools. Therefore, further studies should be conducted with a larger number of Kurdish teachers and learners to examine the correlations between age and proficiency levels to offer more information on the use of the L1 in EFL context by featuring questionnaires, classroom observations, and interviews to find whether similar findings can be produced.

Another further study could be carried out to examine university EFL teachers' and students' attitudes towards the use of the first language in their courses. Finally, students' first language is a tremendously powerful tool that should neither be ignored nor abandoned in English classrooms. It is essential for English language teachers to recognize the usefulness and fruitfulness of students' L1 and attempt to utilize it properly and positively.

\section{APPENDIX}

\section{Teachers' Interview Questions:}

1. What is your native language?

2. How long have you been teaching English?

3. Which levels have you been teaching?

4. Do you teach at public or private school?

5. How many students are enrolled in your class?

6. Do you use Kurdish in your English class? If yes, in which situations?

7. When do you think the code-switching is necessary?

8. What are the advantages and disadvantages of using Kurdish in your English classroom?

9. Many language scholars and academics think that the first language should be excluded from intermediate English classrooms. Do you agree? Why?

10. What are the reasons that encourage you to use or avoid Kurdish in English classroom?

11. Have you tried to apply the English-Only policy in your classroom? Why?

12. How do your students react to the English-Only policy approach?

13. Do you use the first or the foreign language when you manage classroom activities, give instructions, and maintain discipline? Why?

14. What are other factors that make you feel about using Kurdish in your English classroom?

15. If your students do not understand a subject, and they ask you for further explanations, would you prefer to explain it in Kurdish or English? Why?

\section{REFERENCES}

Al-Nofaie, H. (2010). The attitudes of teachers and students towards using Arabic in EFL classrooms in Saudi public schools. Novitas-ROYAL, 4 (1), 64-95.

Atkinson, D. (1987). The mother tongue in the classroom: A neglected resource? ELT Journal, 41(4), 241-247. https://doi.org/10.1093/elt/41.4.241

Atkinson, D. (1993). Teaching in the target language: A problem in the current orthodoxy. Language Learning Journal, $8(1), 2-5$.

Auerbach, E. (1993). Reexamining English only in the ESL classroom. TESOL Quarterly, 27, 9-32. 
Auerbach, E., Barahona, B., Midy, J., Vaquerano, F., \& Zambrano, A. (1996). Adult ESL/Literacy From the Community to the Community: A Guidebook for Participatory Literacy Training. Routledge \& CRC Press.

Azrien, M., Mohamad, S., Mohd, Y. \& Ghazali, Z. (2014). Teachers' Attitudes Towards The Use Of First Language In Arabic Classroom. Journal of Arts, Science \& Commerce. (5).2230.

Baker, C. (2011). Foundations of bilingual education and bilingualism. (3rd ed.). Clevedon: Multilingual Matters.

Bozorgian, H. Fallahpour, S. (2015). Teachers' and students' amount and purpose of L1 use: English as foreign language (EFL) classrooms in Iran. Iranian Journal of Language Teaching Research. 3(2), 67-81.

Brown, D. (2000). Principles of Language Learning and Teaching. New York: Longman.

Buckmaster R. (2002). Using L1: What Kind of Sin? "IATEFL Poland Newsletter" (online) No 18. Retrieved from: http://www.iatefl.org.pl/nletter/nletter18/nlet18_2.html

Burden, P. (2000). The use of the students' mother tongue in monolingual English 'conversation' classes at Japanese universities, The Language Teacher Online, 24(6).

Burden, P. (2001). When do native English-speaking teachers and Japanese college students disagree about the use of Japanese in the English conversation classroom? The Language Teacher, 25(4), 5-9.

Butzkamm, W. (2003). We only learn language once. The role of the mother tongue in FL classrooms: death of a dogma. Language Learning Journal, 28,29-39.

Carless, D. (2008). Student Use of the Mother Tongue in the TaskBased Classroom. ELT Journal 62 (4), 331-338.

Cole, S. (1998). The Use of L1 in Communicative English Classrooms. The Language Teacher. JALT Journal.

Cook, G. (2007). Unmarked Improvement: Values, Facts, and First Languages. IATEFL Conference, Aberdeen, 18-20 April.

Cook, V. (2001). Using the first language in the classroom. The Canadian Modern Language Review, 57(3), 402-423.

Cook, V. (2013). Second Language Learning and Language Teaching (4th ed.). New York: Routledge.

De la Campa, J. \& Nassaji, H. (2009). The Amount, Purpose, and Reasons for Using L1 in L2 Classrooms. Foreign Language Annals. 42(4). 742-759.

Deller, S. \& Rinvolucri, M. (2002). Using the mother tongue: making the most of the learner's language. London: Delta Publishing.

Dixon, Q. L., Zhao, J., Shin, J. Y., Su, J. H., Burgess-Birgham, R., Gezer, M. U. \& Snow, C. (2012). What we know about second language acquisition: a synthesis from four perspectives. Review of Educational Research, 82(5), 560.

Ellis, R. (1984). Classroom Second Language Development. Oxford: Pergamon.

Glazer, M., Harris, K., Ost, D., \& Gower, M. (2017). Creating Bilingual Books to Facilitate Second Language Learning. Journal of Inquiry and Action in Education, 8 (2).

Graddol, D. (2006). English Next: Why global English may mean the end of 'English as a foreign language'. London: British Council, 81-83.

Guest, G., MacQueen, K. M., \& Namey, E. E. (2014). Introduction to applied thematic analysis. Thousand Oaks, California: SAGE Publications, Inc.
Hall, G. \& Cook, G. (2013). Own-language Use in ELT: Exploring global practices and attitudes. London: British Council.

Harbord, J. (1992). The use of the mother tongue in the classroom. ELT Journal, 46, 350-355.

Hasman, M. A. (2000). The Role of English in the 21st Century. FORUM, 38(1).

Hawks, P. (2001). Making Distinctions: A Discussion of the Mother Tongue in the Foreign Language Classroom. Hwa Kang Journal of TEFL, 7, 47-55.

Hiroko, M., Miho, F. \& Mahoney, S. (2004). The Officialization of English and ELT in Japan: 2000. World Englishes. 23(3). 471-487.

Hsieh, L. T. (2000). The effects of translation on English vocabulary and reading learning. Selected papers from the Proceedings of the Ninth International Symposium on English Teaching in the Republic of China. Taipei: The Crane Publishing Co.

Huang, Y. P. (2009). English-only instruction in post-secondary education in Taiwan: Voices from students. Hwa Kang Journal of English Language \& Literature, 15, 145-157.

Husain, K. (1995). Assessing the role of translation as a learning strategy in ESL. International Journal of Translation, 1(2): $59-84$.

Johansson, S. (1998). Loving and hating in English and Norwegian: a corpus-based contrastive study. In D. Albrechtsen, B. Henrikson, I.M. Mees \& E. Poulsen (eds.) Perspectives on Foreign and Second Language Pedagogy (93106). Odense University Press.

Johnson, R. K., \& Lee, P. M. (1987). Modes of instruction: Teaching strategies and student responses. In R. Lord and H. N. L. Cheng (Eds.), Language education in Hong Kong (pp. 99-121). Hong Kong: The Chinese University Press.

Kang, D. M. (2008). The classroom language use of a Korean elementary school EFL teaching: Another look at TETE. System, 36, 214-226.

Kern, R. G. (1989). Second language reading strategy instruction: Its effect on comprehension and word inference ability. Modern Language Journal, 73(2), 135-149.

Kerr, P. (2019). The use of L1 in English language teaching. Part of the Cambridge Papers in ELT series.Cambridge: Cambridge University Press.

Kim Anh, K. H. (2010). Use of Vietnamese in English language teaching in Vietnam: Attitudes of Vietnamese university teachers. ELT Journal, 3(2).

Krashen, S. (1981). Second language acquisition and second language learning. Oxford: Pergamon.

Krashen, S. (1982). Principles and practice in second language acquisition. Oxford: Pergamon Press.

Krashen, S. (1986). Second Language Acquisition Theory. Principles and Practice in Second Language Acquisition, 9-32.

Krashen, S. (1988). Second Language Acquisition and Second Language Learning. London: Prentice Hall International.

Levine, G. S. (2003). Student and instructor beliefs and attitudes about target language use, first language use, and anxiety:Report of a questionnaire study. The Modern Language Journal, 87(3), 343-364.

Liao, P. (2006). EFL learners' beliefs about and strategy use of translation in English learning. RELC, 37(2), 191-215.

Lin, A. M. Y. (2013). Classroom code-switching: Three decades of research. Applied Linguistics Review, 4(1), 195-218. 
Littlewood, W. (1981). Communicative language teaching. Cambridge: Cambridge University Press.

Littlewood, W. \& Yu, B. (2009). First language and target language in the foreign language classroom. Language Teaching, 44(1), 64-77.

Macaro, E. (2001). Analysing Students Teachers' Codeswitching in Foreign Language Classrooms: Theories and Decision Making. The Modern Language Journal, 85, 531-548. http://dx.doi.org/10.1111/0026-7902.00124

Macaro, E. (2005). Codeswitching in the L2 classroom: a communication and learning strategy'. In Llurda, E. (Ed.) Non-Native Language Teachers: Perceptions, Challenges and Contributions to the Profession. New York: Springer, pp. 63-84.

Nation, P. (2003). The role of the first language in foreign language learning. Asian EFL Journal, 5(2), 1-8.

Ortego, P. (1973). Preparation in the Art of Teaching English. Improving College and University Teaching, 21(2), 117120. Retrieved August 1, 2021, from http://www.jstor.org/stable/27564510

Ovando, C. J., Collier, V. P, \& Combs, M. C. (2006). Bilingual and ESL classrooms: Teaching in multicultural contexts (4th Ed.). New York: McGraw-Hill.

Pachler, N.; Field, K. (2001). From Mentor To Co-Tutor: Reconceptualising Secondary Modern Foreign Languages Initial Teacher Education. Language Learning Journal (23). Rugby: Association for Language Learning, 15-25.

Pan, Yi-chun \& Pan, Yi-ching. (2010). The Use of L1 in the Foreign Language Classroom. Colombian Applied Linguistics Journal. 12. 87-96. https://doi.org/10.14483/22487085.85

Phillips, E.M. (1992). The effects of language anxiety on student's oral test performances and attitudes. The Modern Language Journal, 76(1), pp. 14-25.

Phillipson, R. (1992). Linguistic imperialism. Oxford: Oxford University Press.

Polio, C. (1994). Comment on Else Roberts Auerbach's "Reexamining English Only in the ESL Classroom". TESOL Quarterly, 28 (2):153-161.

Prodromou, L. (2002). From mother tongue to other tongue. Teaching English.

Ramachandran, S. D., \& Rahim, H. A. (2004). Meaning recall and retention: The impact of the translation method on elementary level learners' vocabulary learning. RELC Journal, 35(2), 161-178.

Richards, J., \& Rodgers, T. (2001). Approaches and Methods in Language Teaching (p. 204). New York: Cambridge University Press.

Rolin-Ianziti, J., \& Varshney, R. (2008). Students' views regarding the use of the first language: An exploratory study in a tertiary context maximizing target language use. Canadian Modern Language Review, 65(2), 249-273.

Scheffler, P. \& Domińska, A. (2018). Own-language use in teaching English to preschool children. ELT Journal 72(4): pp.374-383.

Schweers, C.W., Jr. (1999). Using L1 in the L2 Classroom. English Teaching Forum 37 (2), 6-9. Survey "The Use of Mother Tongue".

Scott, V. M., \& de la Fuente, M. J., (2008). What's the problem? L2 learners' use of the L1 during consciousness-raising, form-focused tasks. The Modern language Journal, 92(1), 100-113.
Seng, G. H., \& Hashim F. (2006). Use of L1 in L2 reading comprehension among tertiary ESL learners. Reading in a Foreign Language, 18(1).

Storch, N., \& Wigglesworth, G. (2003). Is there a role for the use of the L1 in an L2 setting? TESOL Quarterly, 37(4), 760770.

Swain, M., \& Lapkin, S. (2000). Task-based second language learning: the uses of the first language. Language Teaching Research, 4(3), 251-274.

Thornbury, S. (2010). $T$ is for translation. Retrieved from: http://scottthornbury.wordpress.com/2010/04/21/t-is-fortranslation/

Tsao, J.X. \& Lin, H.X. (2004). The impact of the language used in the English classes on the psychological and learning aspects of the students in the technical andvocational system of education in Taiwan. Proceedings of 2004 International Conference and Workshop, Taiwan. 482494.

Turnbull, M. (2001). There is a role for the L1 in second and foreign language teaching. Canadian Modern Language Review, 57(4), 531.

Turnbull, M., \& Arnett, K. (2002). Teachers' uses of the target and first languages in second and foreign language classroom. Annual Review of Applied Linguistics, 22, 204-218.

Vanderheijden, V. (2010). Is that English I hear over there? Rethinking the prohibition on L1 use in foreign language learning. TPFLE, 14 (1), 3-17.

Villamil, O., \& de Guerrero, M. (1996). Peer revision in the L2 classroom: Socio-cognitive activities, mediating strategies, and aspects of social behavior. Journal of Second Language Writing,5, 51-75.

Vygotsky, L. S. (1978). Mind in society: The development of higher psychological processes. Cambridge, MA: Harvard University Press.

Weschler, R. (1997). Uses of Japanese in the English Classroom: Introducing the Functional-Translation Method. Kyoritsu Women's University Department of International Studies Journal, 12, 27.

Willis, D. and Willis, J., (2007). Doing task-based teaching. Oxford: Oxford University Press.

Yphantides, J. (2009). Student use of Japanese in the EFL classroom. Accents Asia, 3(2), 1-26. 